American Journal of Qualitative Research

2021, Vol. 5 No. 2, pp. 130-155

https://doi.org/10.29333/ajqr/11151

(C) 2021 AJQR. http://www.ajqr.org
AMERIGAN

JOURNAL OF QUAUTATIVE

RESEARCH

ISSN: 2576-2141

\title{
Supporting Teacher Change in an English as a Foreign Language Environment: A Peer-Coaching Study in Turkey
}

\author{
Arzu Gul ${ }^{1}$ \\ State University of New York (SUNY), Plattsburgh, USA \\ Wendy C. Kasten \\ Kent State University, USA
}

\begin{abstract}
Even though Ministry of National Education (MoNE) in Turkey has been switching from the traditional approach to the constructivist one since 2005, the classroom practices, teaching methods, evaluation system, school structures and materials, and the aspects of the administrators and teachers are still contrary to the principles of constructivism. This study offered constructivism as a new notion in teaching English as a foreign language for six willing teachers. Following a 10day professional development seminar, the impacts on teachers' change were observed. Data sources included: participant periodic interviews, observational fieldnotes and artifacts; and researcher logs. The findings showed that the treatment plan was effective to enable teachers learn constructivism, change their approach, and applications. This study provided noteworthy findings regarding professional development seminars. A well-planned and well-organized teacher development seminar with an on-going support and peer coaching is necessary. Professional development communities and critical conversation groups have notable roles in teacher development. This study also showed that teachers are the most important actors in implementing educational change as they can reach their idealistic (constructivist) goals regardless of obstacles such as time constraint, overcrowded classes, and insufficient materials.
\end{abstract}

KEYWORDS: Constructivism, English as a Foreign Language (EFL), Peer-Coaching, Professional Development Seminar, Teacher Change.

English as a foreign language is still taught in Turkey in traditional ways, which are mainly grammar teaching, text translation, and correctness rather than meaning making (Can, 2009; Demircan, 1988; Demirel, 2003; Luk, 2006; Reinfried, 2000; Ulum \& Uzun, 2020). Students are memorizing words, without the ability to construct sentences; learning advanced-level grammar without the ability to speak and understand; and participating in language learning without meaningful active engagement. All of this causes them to dislike the foreign language classes (Agopian, 2019; Buyukduman, 2005; Er, 2006; Ersen-Yanik, 2008; Kavanoz, 2006; Kirkgoz, 2005, 2009; Sad, 2010).

\footnotetext{
${ }^{1}$ Corresponding Author E-mail: agul001@plattsburgh.edu
} 
Because these traditional approaches have these drawbacks, EFL teachers need more effective language learning strategies. Constructivism is an important approach in education, particularly in foreign language learning due to its focus on integrating all of the components of communicative competence (Agopian, 2019; Demircan, 1988; Dewey, 1916; Gao, 2021; Lou, 2008; Luk, 2006; Piaget, 1973; Reinfried, 2000; von Glasersfeld, 1995; Vygotsky, 1978). Moreover, in a constructivist approach, the language learning strategies are designed to effectively engage learners for more meaningful purposes with reading, writing, speaking and listening (Agopian, 2019; Can, 2009; Demircan, 1988; Reinfried, 2000).

Teachers throughout the country of Turkey are mandated to use the identical curriculum for foreign language teaching, which is designed by the Turkish Ministry of National Education (MoNE), just like the other educational activities at schools which are designed as a national curriculum and are controlled by superintendents assigned by the MoNE (Baglibel, Samancioglu, \& Crow, 2018; Cakiroglu \& Cakiroglu, 2003; Demircan, 1988; Kirkgoz, 2005, 2009 Seferoglu, 1996). On paper, the curriculum looks perfect and every single detail including methods, goals and objectives, grammar, vocabulary teaching, and all skills (reading, writing, speaking, and listening) are included (Demircan, 1988; Luk, 2006; MoNE, 2009). Based on the curriculum documents, a reader could be assumed that all students would be at an advanced proficiency level in English, and know English almost as well as their mother tongue when they graduate from high schools. However, in reality, this is not the case (Dogancay-Aktuna \& Kiziltepe, 2005). Students just learn grammar structures and vocabulary without gaining any speaking or listening ability.

The students in Turkey are learners of English as a Foreign Language (EFL); which means they try to learn a foreign language in a country of which the national language is not English (Brown, 2000; Mitchell \& Myles, 2004) as, compared to English as a Second Language (ESL) learners. EFL learners are disadvantaged as they miss the opportunities to hear the language by native speakers and begin to understand context.

In classrooms, students have limited time to be exposed to the target language. Especially in public schools, instruction is generally done in the first language. Teachers usually speak about the language while presenting the sentence structures and grammar rules of the target language but they rarely speak in the target language. Thus, almost no listening for the learners takes place. As a result, students do not gain speaking and listening abilities (Kara, Ayaz, \& Dundar, 2017).

In addition, public schools are overcrowded, which in turn limits a teacher's ability to interact with every student (Ashraf, 2021; Ayu, 2019; Kucukler, \& Kodal, 2019; Kirkgoz, 2009). In these overcrowded classes of 30 or more, students hardly have the chance to practice the language they are learning. As seen from the problems briefly mentioned, traditional methods in schooling do not meet the foreign language education goals and objectives, one of which is to have students who are able to engage in conversations, express feelings, and exchange opinions in English (Demircan, 1988; Kucukler \& Kodal, 2019; MoNE, 2009).

Even though the Ministry of National Education (MoNE) in Turkey has been switching from the traditional approach to the constructivist one since 2005 in theory, the classroom practices, teaching methods, school structures and materials, and the aspects of the administrators and teachers are still traditional and contrary to the principles of constructivism (Aykac, 2007a, 2007b; Aykac \& Ulubey, 2012).

In order to implement such an adjustment, foreign language teachers are the most important players (Cakiroglu \& Cakiroglu, 2003; Garet, Porter, Desimone, Birman \& Yoon, 2001; Kirkgoz, 2009; Nolan \& Meister, 2000; Yilmaz, 2009) and should be introduced with the new system and trained via teacher training/professional development experiences (Agopian, 2019; Aksoy, Bozdogan, Akbas, \& Seferoglu, 2018; Ayvaz-Tuncel, \& Cobanoglu, 2018; Fullan, 2001; Munoz, 
2007; Richards \& Farrell, 2005; Seferoglu, 1996; Stein \& Wang, 1988; Yilmaz, 2009). It should be noted that the teachers are adult learners where they like to bring and share their own experiences, participate in task-based activities, and construct their knowledge in a more complex way (Knowles, 1996; Moore, 1988; Sessions, 1995). Further, peer coaching, which is a process where teachers work together on current practices and help develop new skills by sharing ideas and experiences (Sessions, 1995), and collaboration is an essential component of teacher development and training (Garmston, 1987; Johnson \& Johnson, 1987; Joyce \& Showers, 1982, 1987; Pugach \& Johnson, 1990; Robbins, 1991; Showers, 1982, 1984, 1985; Tomlinson, 2019).

The professional development seminars and experiences, and thus the quality of teaching, are not high priority of MoNE in Turkey (Ayvaz-Tuncel, \& Cobanoglu, 2018; Gokmenoglu, Clark, $\&$ Kiraz, 2016). Therefore, as one study conducted on 494 teachers showed the in-service training did not contribute to the professional development of the teachers due to the negative views of the trainers, poor and inappropriate settings of the seminar rooms, and lack of participants' inclusion in seminar planning and evaluation (Ayvaz-Tuncel, \& Cobanoglu, 2018).

\section{Constructivism}

Constructivism is "neither a person nor a method, but a theory of knowledge" (MacKinnon \& Scarff-Seatter, 1997, p. 54). Further, it is a lens that lets people see and interpret the world in many various ways. Scholars and philosophers such as Dewey (1916), Piaget (1973), and Vygotsky (1978) had different perspectives and ideas on constructivism although they were arguing mainly around the same epistemology and ontology. In other words, the scholars interpreted the same concept from their different angles, experiences, minds, and worlds.

There is an emphasis on the action and experience in education, in a classroom context and setting, where the learners build their knowledge by manipulating the materials. When the students experience something, they can take action accordingly, and when they do something to the thing, then it does something in return (Dewey, 1916).

The traditional education system for providing only specific prescription and dictation or providing only fixed and ready models is criticized. They do not necessitate the perception and explanation of ends, nor do they allow applying judgment in selecting and adapting means (Dewey, 1916). Therefore, more a participative, creative, and constructive way of education for the students is vital.

The development of child (cognitive) psychology in education is also important in constructivism. The learners construct their knowledge to know their world. Therefore teachers should consider the stages and steps of child's mental development in teaching (Piaget, 1973). Piaget claimed that the child must pass through some stages that were formed by the ideas, which will be considered wrong at the beginning but essential later for the final correct solution. Stages should be taken into consideration when providing learning materials and doing activities. Further, the students' motor and/or mental level should be considered, and any kind of requirement that is beyond that level should be avoided, because they may not be able to do some things if they have not reached the relevant stage already. Children's thinking makes a gradual increase in knowledge and intellectual skills towards logical thinking.

Children are active learners, who are always in an interaction with their environment. They should be provided a classroom environment where they are involved with activities and practices of their interest in discovering and exploring relationships and other phenomena of the situations. In order to form the students as being capable of production and creativity, the appropriate 
conditions should be provided to them (Cambourne, 2001; Piaget, 1973). This way they can have the chance to learn and understand by discovering.

Another point in constructivism is that children learn the scientific concepts from tension that exists between their everyday perception and things around them (Vygotsky, 1978). They will possess concepts, which were memorized from an adult, only when they use and link it. While linking the solutions of problems, the speech has a significant effect on the child's activity. The previous conceptions and the introduced scientific notions are not linearly and straightly connected. They are intertwined, and each may influence the other as the child exercises his or her formerly known ideas with the lately introduced ones.

Social interaction and social context are crucial in the cognitive development. According to Vygotsky (1978), the functions of children's cultural development happen at the social level first and then at the individual level. Put differently, it functions between people (interpsychological) first and later inside the children (intrapsychological), which relates to voluntary attention, to logical memory, and to the concept formation. He argued about the zone of proximal development (ZPD or Zo-ped), which is "the distance between the actual developmental level of a child as determined by independent problem solving and the level of potential development as determined through problem solving under adult guidance or in collaboration with more capable peers" (p. 86). So, the guidance, help, and support can make children understand things better and develop more compared to doing something alone. Further, Vygotsky mentioned that language is an important component and tool for the child to create new chances for doing things and for organizing information. Therefore, the more comprehensive and loaded language experience given to the children within the ZPD, the more they learn, because the class activities generate a teaching environment.

From a different perspective, constructivism is more than just a learning theory; it is seeing the world from a broader perspective where various interpretations are present to shed light on the complex and abstract phenomena (von Glasersfeld, 1995, 1998). Further, constructivism is an unconventional approach where it assumes that knowledge is in the heads of people. Therefore, there is no other way but to construct what they know based on their experiences (von Glasersfeld, 1995).

Motivation is also important in constructivism. If the students know why the thing they learn is useful, they would be more motivated to learn (von Glasersfeld, 1995). The traditional schooling system makes the students study for passing exams, rather than becoming more intellectually knowledgeable. In radical constructivism, there is more than just one right way or a fixed teaching procedure. Constructivism "cannot tell teachers new things to do, but it may suggest why certain attitudes and procedures are fruitless or counter-productive; and it may point out opportunities for teachers to use their own spontaneous imagination" (von Glasersfeld, 1995, p. 177). So, it can be said that constructivism provides a theory of knowledge, communication, and the learning process that could help and guide all teachers to start using their own imagination and creativity (von Glasersfeld, 1998).

Overall, constructivism is different than positivist approaches in terms of epistemology and ontology (Brooks \& Brooks, 1999; Goodman, 2005; Oxford, 1997). What all of the abovementioned scholars argue is that the knowledge is not out there independent from the subject, but constructed by the subject, and, it is not something objective. In constructivism, the education is not as simple and linear as claimed but it is a complex issue that should be taken more seriously (Brooks \& Brooks, 1999). Moreover, the students are more important and featured not to be treated based on the experiment results done on rats or pigeons (Goodman, 2005). 


\section{Professional Development for Teachers}

Professional development, which is the "Systematic efforts to bring about change in the classroom practices of teachers, in their attitudes and beliefs, and in the learning outcomes of students" (Guskey, 2002, p. 381) is important and necessary for the teachers' improvement (Agopian, 2019; Ayvaz-Tuncel, \& Cobanoglu, 2018; Fullan, 2007; Garet et al., 2001; Lund, 2020; Noom-ura, 2013; Richards \& Farrell, 2005) as the teachers are the ones that should be invested in first and foremost in order to increase the quality of education (Yilmaz, 2009).

Since new issues, problems, and ways continuously exist, it is critical to have continuous teacher development to keep the teachers updated and equipped with the latest thinking and strategies. Continuing professional development is important for teachers' development because experience alone is not sufficient (Richards \& Nunan, 1990). For instance, Noom-ura (2013) examined the problems with English language teaching and learning and the professional development (PD) needs of high-school teachers in three provinces of three Secondary Educational Service Areas in Thailand using closed-and open-ended questionnaires applied on 34 English teachers. Noom-ura (2013) found that professional development experiences have a critical role in increasing the quality level of teachers and enhancing their teaching skills (i.e., communication skills).

Even though teachers are usually required to participate in professional development, dedicated teachers genuinely want to join opportunities to become better teachers and improve their practice (Fullan, 1993; Guskey, 2002). Therefore, the teachers' "belief that it will expand their knowledge and skills, contribute to their growth, and enhance their effectiveness with students" (Guskey, 2002, p. 382) motivates them to join seminars.

Since teachers have this great responsibility of continuing education, they need a continuous support of professional development to carry out their lifelong learning (Ayvaz-Tuncel, \& Cobanoglu, 2018; Garet et al., 2001; Guskey, 2002; Munoz, 2007; Richards \& Farrell, 2005; Seferoglu, 1996; Stein \& Wang, 1988; Yilmaz, 2009). New methods in teaching that are introduced to the teachers by teacher training/professional development seminars could contribute to teachers' self-image, their perception of their profession, the way they view their students, and the quality of their teaching (Lund, 2020; Munoz, 2007; Richardson, 1990; Seferoglu, 1996; Tante, 2010).

Different models for professional development have been tried to alleviate the gap between theory and practice, and to attempt ways to make professional development truly effective (Babinski et al., 2018; Holly, Arhar, \& Kasten, 2009). Peer coaching, defined as a "confidential process through which two or more professional colleagues work together to reflect on current practices; expand, refine, and build new skills; share ideas; teach one another; conduct classroom research; or solve problems in the workplace" (Sessions, 1995, p. 11) is one model shown to be effective.

In peer coaching, two or more teachers go through professional development together, and coach each other in their classroom settings (Babinski et al., 2018; Garmston, 1987; Johnson \& Johnson, 1987; Joyce \& Showers, 1982, 1987; Pugach \& Johnson, 1990; Robbins, 1991; Showers, 1982, 1984, 1985; Tomlinson, 2019).

One reason peer coaching is effective is that adult learning is different than young and children learning in several ways (Knowles, 1996; Moore, 1988; Sessions, 1995). As Knowles (1996) lays out, adults want to know why they need to learn; need to take responsibilities while learning; want to bring their experiences to their learning; want to learn when they feel they need it; and want to learn when learning is task-oriented. Moreover, adults like to participate in discussions where they can share and learn experiences (Moore, 1988). There are more experiences 
that can be used as learning resources: adults tend to learn "for specific purposes," and they want "to apply what had been learned immediately" (Sessions, 1995, p. 28). Different than young learners, adult learners construct knowledge in a more complex way. Peer coaching and collaboration are essential (Garmston, 1987; Johnson \& Johnson, 1987; Joyce \& Showers, 1982, 1987; Pugach \& Johnson, 1990; Robbins, 1991; Showers, 1982, 1984, 1985).

Peer coaching has been found to be effective professional development in a number of ways. It has been found that teachers solve most of their teaching problems (Pugach \& Johnson, 1990; Tomlinson, 2019), increase their overall knowledge of varied approaches (Johnson \& Johnson, 1987), practice varied strategies more frequently, and exhibit clearer professional thinking. Moreover, teachers teach more effectively, and deepen both professional dialogue and collegiality (Garmston, 1987; Joyce \& Showers, 1987; Lund, 2020; Showers, 1982, 1984, 1985).

As an English teacher in Turkey, the researcher had always been interested in exploring the new theories and methods in foreign language teaching. With the help of her graduate studies in the United States, she became aware of the importance of using constructivist best practices both in education in general and in foreign language education. They also helped her realize that professional development seminars, and thus the quality of teachers, were not a high priority of MoNE in Turkey.

In order to increase the quality of education, the teachers are the ones that should be invested first and most (Yilmaz, 2009). In that regard, to introduce the constructivist best practice to six selected English teachers in Turkey through a 10-day professional development seminar, this study explores how these English teachers understand constructivism as a new notion in education and how they apply it into its practice. The researcher aimed to facilitate and encourage participants in thinking and learning by providing various resources, information, framework, and guidance through the professional development seminar to help them become critically reflective teachers. It was advantageous for the researcher to work with a group of teachers from Turkey in this study as she shared the same cultural and educational background, which made the research process more meaningful and convenient.

\section{Methodology}

The goal of this study was to introduce the constructivist approach in foreign language education to six selected English teachers in Turkey and explore and interpret how they applied this newer theory into practice. It was also intended to see what insights could be gained about doing professional development in foreign language teaching in the context of Turkey.

Using a qualitative methodology in the form of interviews, observational fieldnotes, a researcher log, and artifacts were sources of data. The research questions were:

1. How do selected English teachers in Turkey understand constructivism as a new notion in foreign language education?

2. How do the teachers apply constructivism into their foreign language teaching?

3. What insights can be gained about doing professional development in foreign language teaching in Turkey? 


\section{Participants}

The researcher used a nonrandom and purposeful sampling where "the inquirer selects individuals and sites for study because they can purposefully inform an understanding of the research problem and central phenomenon" (Creswell, 2007, p. 125). The researcher selected six English teachers from two public schools in two neighboring administrative districts in Ankara, Turkey. The main criterion in the selection of the teachers was their being English teachers in either public middle or high schools teaching at a variety of grade levels ranging from the 5th to 11th grades. Second, the participants were at least a graduate of a four-year college. Finally, they had at least 10 years of teaching experience.

The researcher selected the participants based on voluntary criteria and had them sign a consent form to take part in this research. The researcher provided thorough information about the research project and answered the possible questions from the volunteers regarding the project to eliminate the questions in their minds. This way, it was hoped that the project was implemented properly and democratically.

\section{Table 1}

Demographic Information of the Participants

\begin{tabular}{|c|c|c|c|c|c|c|}
\hline Participant & Gender & $\begin{array}{l}\text { Age } \\
\text { Range }\end{array}$ & $\begin{array}{l}\text { Undergraduate } \\
\text { Education (BA) }\end{array}$ & $\begin{array}{c}\text { Graduate } \\
\text { Education } \\
\text { (MA, } \\
\text { PhD) }\end{array}$ & $\begin{array}{c}\text { How } \\
\text { Long } \\
\text { English } \\
\text { Teaching }\end{array}$ & $\begin{array}{c}\text { Teaching } \\
\text { Grades This } \\
\text { Semester }\end{array}$ \\
\hline P1: Ebrar & Female & $31-35$ & $\begin{array}{l}\text { Faculty of } \\
\text { Education }\end{array}$ & MA & 13 & 9,10 \\
\hline P2: Esra & Female & $36-40$ & $\begin{array}{l}\text { Faculty of } \\
\text { Education }\end{array}$ & & 15 & $9,10,11$ \\
\hline P3: Gamze & Female & $31-35$ & $\begin{array}{l}\text { Faculty of } \\
\text { Education }\end{array}$ & $\begin{array}{l}\mathrm{MA} \\
\mathrm{PhD}\end{array}$ & 14 & $5,6,7$ \\
\hline P4: Hale & Female & $26-30$ & $\begin{array}{l}\text { Faculty of } \\
\text { Education }\end{array}$ & Student & 10 & $5,6,7,8$ \\
\hline P5: Nil & Female & $36-40$ & $\begin{array}{l}\text { Faculty of } \\
\text { Education }\end{array}$ & & 13 & $9,10,11$ \\
\hline P6: Zeynep & Female & $36-40$ & $\begin{array}{l}\text { Faculty of } \\
\text { Arts and } \\
\text { Sciences }\end{array}$ & & 15 & $5,6,7$ \\
\hline
\end{tabular}

Selecting participants from the schools that were not very far from each other, it was expected to provide the researcher with some important advantages. For example, the teachers were easily accessed whenever needed especially during the data collection process when class 
observations and interviews took place. Creswell $(2007,2009)$ affirmed the importance of this issue by saying that it is important for the researcher to find people who are easily accessible. In addition, selecting the teachers from close schools allowed them to have critical conversations and discussions with each other.

The participants of this study were six English teachers working in two public schools in two neighboring administrative districts in the city of Ankara, Turkey. All participants of the study unintentionally were females. In order to protect the participants' privacy, the researcher used pseudonyms. Details about the participants were presented in Table 1.

The researcher worked with this group of teachers from Turkey because both the researcher and the participants shared the same cultural and educational background, which made the research process more meaningful.

\section{Settings}

The research was conducted in two public schools in Ankara, and the participants were observed in their classrooms.

Schools. Two public schools were selected in two different administrative districts of the city of Ankara: Yenimahalle and Kecioren. They were neighboring districts where the researcher easily visited the participants from both schools in a day. The school located in Kecioren had 39 teachers; five of whom were English teachers. There were 625 students studying from the fourth to eighth grades in that school. Girls and boys attended the classes together. The school provided a dual (morning and afternoon) session for the students.

The school located in Yenimahalle had 130 teachers eight of whom were English teachers. There were 2,250 students studying from the 5th to 12th grades in that school. Girls and boys studied in separate classes and they attended the school full day.

Classroom settings. Since both of the schools were public, they were highly crowded (approximately 30 or more students). Neither of the schools had any technological equipment in the classrooms, but the teachers could bring the necessary equipment and tools borrowing from the relevant office to use.

\section{Treatment}

A 10-day professional development seminar was given to the six selected English teachers in order to introduce constructivism and constructivist activities which were demonstrated by the researcher during the seminar. This seminar was organized and given in non-traditional ways and settings as constructivism requires. In every seminar meeting, a nice, warm, and relaxed atmosphere was provided for the participants to get them engaged in the workshop. This kind of environment caused the participants to get involved with each other collaboratively and collectively. It also enhanced the participants' motivation and strengthened the relationships among them.

In this context, the seminar was given in the conference hall at the school located in Yenimahalle. It lasted for two weeks starting on September $1^{\text {st }}, 2014$ and ending on September $12^{\text {th }}, 2014$. The morning sessions started at 11:00 am and ended at 12:30 pm. After one-hour break, the afternoon sessions started at 1:30 pm and ended at 3:00 pm every weekday for two weeks. The only exceptions were the Fridays; the participants were free in the afternoon on Friday, the fifth day of the seminar. The last session of the seminar on the second Friday lasted for one hour only. 


\section{Data Collection}

Data collection is a "series of interrelated activities aimed at gathering good information to answer emerging research questions" (Creswell, 2007, p. 118). In this study, demographic interviews and surveys, interviews, in-class observational field notes, artifacts, and researcher logs were used as data collection sources. A summary of data collection methods is found in Table 2.

\section{Table 2}

\section{Data Collection Methods}

\begin{tabular}{|c|c|c|}
\hline $\begin{array}{l}\text { Q 1: How do selected } \\
\text { English teachers in Turkey } \\
\text { understand constructivism } \\
\text { as a new notion in foreign } \\
\text { language education? }\end{array}$ & $\begin{array}{l}\text { Q 2: How do they apply } \\
\text { constructivism into their } \\
\text { teaching? }\end{array}$ & $\begin{array}{l}\text { Q 3: What insights can be } \\
\text { gained about doing } \\
\text { professional development } \\
\text { in foreign language } \\
\text { teaching in Turkey? }\end{array}$ \\
\hline $\begin{array}{l}\text { Pre-workshop demographic } \\
\text { interview and survey at the } \\
\text { beginning of the study } \\
\text { Five, one-hour-long } \\
\text { interviews, all of which are } \\
\text { tape-recorded } 30 \text { hours in } \\
\text { total }\end{array}$ & $\begin{array}{l}\text { Five, one-hour-long } \\
\text { interviews, all of which are } \\
\text { tape-recorded } 30 \text { hours in } \\
\text { total }\end{array}$ & $\begin{array}{l}\text { Five, one-hour-long } \\
\text { interviews, all of which are } \\
\text { tape-recorded } 30 \text { hours in } \\
\text { total }\end{array}$ \\
\hline $\begin{array}{l}\text { In-class observational } \\
\text { fieldnotes (three times for } \\
\text { each participant during the } \\
\text { Fall } 2014 \text { semester) }\end{array}$ & $\begin{array}{l}\text { In-class observational } \\
\text { fieldnotes (three times for } \\
\text { each participant during the } \\
\text { Fall } 2014 \text { semester) } \\
\text { Artifacts- student } \\
\text { generated written work } \\
\text { when written work is part } \\
\text { of the teacher's lesson and } \\
\text { in-class observational field } \\
\text { notes }\end{array}$ & $\begin{array}{l}\text { In-class observational } \\
\text { fieldnotes (three times for } \\
\text { each participant during the } \\
\text { Fall } 2014 \text { semester) }\end{array}$ \\
\hline $\begin{array}{l}\text { Researcher log }(20 \operatorname{logs} \text { in } \\
\text { total, } \\
10 \text { of them during the } \\
\text { professional development } \\
\text { seminar, and the other } 10 \\
\text { during the Fall } 2014 \\
\text { semester) }\end{array}$ & $\begin{array}{l}\text { Researcher log }(20 \text { logs in } \\
\text { total, } \\
10 \text { of them during the } \\
\text { professional development } \\
\text { seminar, and the other } 10 \\
\text { during the Fall } 2014 \\
\text { semester) }\end{array}$ & $\begin{array}{l}\text { Researcher log }(20 \text { logs in } \\
\text { total, } \\
10 \text { of them during the } \\
\text { professional development } \\
\text { seminar, and the other } 10 \\
\text { during the Fall } 2014 \\
\text { semester) }\end{array}$ \\
\hline
\end{tabular}

All interviews were tape-recorded, and the conversations were transcribed. The researcher used "member checking" (Lincoln \& Guba, 1984, p. 314) by having the participants read the transcriptions to see if she understood them correctly and avoid misunderstandings and misinterpretations. She also used the "peer debriefing" (p. 308) technique by having two Turkish colleagues with $\mathrm{PhDs}$ in reading review the interview transcriptions to establish credibility. 


\section{Data Analysis}

This study did a systematic plan for analyzing and interpreting the data to be able to describe the process of introduction of constructivism to the six selected English teachers and their application of this new notion into foreign language teaching in two public schools in two neighboring administrative districts in Ankara.

The main objective of the data analysis was to organize, synthesize, and make sense of the data collected to write a description that explained the language teaching processes and settings of each participant. Data analysis was done using an inductive analysis approach to search for patterns of meaning in the data so that reasonable conclusions were drawn from them. Data were derived and organized mostly from the audio transcripts and the researcher's notes.

The concepts and themes of the data collected through demographic surveys, interviews, in-class observational fieldnotes and artifacts, and researcher logs were processed and elaborated. Then, they were coded to be able to readily retrieve and examine the data units that referred to the similar subjects (Rubin \& Rubin, 2005). After the coding, data were classified into categories, and analyzed within and across the groups of related items, topics, and subjects. The researcher tried to make interpretations to explain, to give meaning, to make sense of the many disparate events and ideas that encountered about the research problems (Holly, Arhar, \& Kasten, 2009), and draw meaningful conclusions from the data gathered. Not only were the meanings gotten that the participants held, but also an interpretation of what was seen, heard, and understood was also made. Since the interpretation was an ongoing process, there was a continuous analysis in case new patterns and themes could be found to get more meaningful and realistic conclusions. Finally, how these concepts, themes, and patterns proposed answers to the research questions of the study, were shown (see the Appendix for a sample of data coding and analysis).

The categories which emerged are: Teachers were not aware of the new system, Teachers are key persons, Time constraint, lack of materials, overcrowded classes, Teacher change, Evaluation system still traditional, Holistic approach necessary, Teacher development seminar, Choice matters, everyone was bored, everyone was happy, Helps every level of student, Constructivism more effective in teaching, Motivation, Seminar effect continued, Professional community and critical conversation groups. The findings are reported in the next section by categories.

\section{Findings and Discussion}

The findings of this study also revealed several important issues regarding teacher development seminars, teacher change, constructivist applications, and challenges as presented below.

Teachers were not aware of the new system. The Ministry of National Education (MoNE) in Turkey educational reform referred to earlier was meant to move education towards a constructivist approach; however, the new education system has not been applied as successfully as planned on paper, in practice. Teachers were not well informed about the changes, and professional development towards change was inadequate (Bamgbose, 2003; Donmez, 2010; Topkaya \& Kucuk, 2010).

Teachers are key persons. Supporting the literature, one of the outcomes of this study was the teachers were the key persons and the primary implementers of an education system (AyvazTuncel, \& Cobanoglu, 2018; Cakiroglu \& Cakiroglu, 2003; Garet et al., 2001; Geringer, 2003; Kirkgoz, 2009; Nolan \& Meister, 2000; Yesilcinar \& Cakir, 2018; Yilmaz, 2009). In spite of all 
challenges, the teachers in this project succeeded to apply constructivist principles. Teachers need to be engaged with any changes in curriculum and teaching (Fullan, 2001).

Time constraint, lack of materials, overcrowded classes. This study revealed that there were some problems, such as time constraints, lack of materials, and overcrowded classrooms that might affect the constructivist applications just as other studies have shown (Ashraf, 2021; Aykac, 2007a; Aykac \& Ulubey, 2012; Ayu, 2019; Buyukduman, 2005; Demir-Ayaz, Ozkardas, \& Ozturan, 2019; Kucukler, \& Kodal, 2019; Ulum \& Uzun, 2020;). For instance, Esra quoted:

Especially the classes are overcrowded. Boys' classes are 30-40 or more. In such classes, I can only deal with and/or interact with 10-15 students effectively and efficiently.

Teacher change. All of the data show that the teacher development seminar was effective. The participants changed in their views and applied constructivist methods. These findings are supported in the literature (Agopian, 2019; Lou, 2008; Lund, 2020; Noom-ura, 2013).

The participants indicated they were reborn in terms of being a teacher and noticed their weaknesses and mistakes. This finding was parallel with Richards and Farrell's (2005) argument that teacher development had a goal, which was to help teachers understand their teaching and themselves as teachers. Zeynep quoted: "This teacher development seminar has been a turning point for me. I liked the contents, activities, and applications. I was confident that I was a successful teacher, but this seminar fortified my feelings that I will be much more successful in the future." Hale said, "It wouldn't be wrong to say that I acquired so many new ideas that I will use during not only this semester but also the whole teaching life. The traditional teaching perspective/approach that I had before completely changed." Esra admitted: "This project and seminar made me notice my capacity. It made me re-think about how far I could go and endure with problems. I got some ideas on what kind of activities I could do. I also realized the mistakes I have done so far."

Evaluation system still traditional. One of the findings was that the evaluation system was still traditional which, in turn, was not compatible with the constructivist applications. This was also a reason for the failure in switching to constructivist approach by MoNE (Aykac, 2007a, 2007b; Aykac \& Ulubey, 2012; Ulum \& Uzun, 2020). When the MoNE changed the education system, the evaluation aspect was ignored. Whereas the learning and teaching in the new system was process-based, the evaluation system was still outcome-based. Teachers were still required to do traditional written exams at least three times a semester. There were also nationwide standardized tests for the students to enter secondary and higher education. As Hale indicated,

Evaluation is the very end of the teaching process. You cannot totally get disconnected from it. The system does not allow you to do that. If I do a lot of speaking with the students, does it matter? No, because there is not a place for speaking in the evaluation system.

Holistic approach necessary. In order to have change, there should be a holistic approach (Aykac, 2007a, 2007b; Aykac \& Ulubey, 2012; Bagilibel, et al., 2018). In other words, after the change was announced and proceeded, the MoNE did not prepare the textbooks and some other teaching materials accordingly, which was one of the critical challenges for teachers. Esra said, 
While conducting constructivist applications, I sometimes have difficulty in trying to follow the curriculum and catch up with the units of the textbook. As everyone knows that standardized tests are prepared based on the textbooks and grammar. Further, when inspectors come, they ask questions on the one type curriculum.

Gamze said, "Constructivism is great and beneficial as long as the textbooks and testing system are adjusted accordingly. Otherwise, the whole application may fail at some point due to those centralized and national level incompatibilities and inconsistencies".

Teacher development seminar. The current project was successful overall in terms of managing teacher change. In that regard, one of the outcomes of this study was that a well-prepared teacher development seminar (based on constructivist criteria) with sufficient consulting and mutual collaboration might help the teacher change as well as internalize the new system. This finding mainly supported the arguments in the literature (Agopian, 2019; Aksoy et al., 2018; Babinski et al., 2018; Geringer, 2003; Guskey, 2002; Hargreaves \& Fullan, 1992; Lund, 2020; Rohmah, 2018). The participants also indicated that they rarely had seminars before, but none of them left positive impacts on them. This argument parallels the study of Ayvaz-Tuncel and Cobanoglu (2018).

Once the teacher was trained, persuaded, and motivated, that teacher could implement anything in spite of several obstacles and challenges. The main reasons for this seminar being effective, as expressed, were the continuing consultation, cooperation, and follow up with the researcher. The participants wanted to reach someone easily when they needed or got stuck in application. Topkaya and Kucuk (2010) indicated that such development seminars and platforms where teachers could get together; share and exchange experiences and implementations of the new program were necessary. Such seminars might be good for them to see how to overcome problems during the application of a new program. Nil quoted:

In addition, I also learned from the seminar that we should not load the students with a lot of information. Once, you said that we should focus on fewer topics with more in depth, rather than many topics with little bits of information. Somehow, I felt like I needed to cover everything about English such as grammar, reading, speaking, and vocabulary. I no longer do that.

Hale said,

Because of you and this seminar, I had a wonderful and very successful semester. I have also enjoyed the constructivist approach. If I was not convinced at the beginning, I would not be able to apply it. Everything developed way better than I expected.

Choice matters. One of the things gained in this study was that the choice matters in attending the professional development seminars. In other words, when the participants were forced to participate, or when they were not given choices, it backfired in one sense, and things did not go as planned. As expressed by one of the teachers in this project, the feeling of being free and voluntary to participate in the seminar was an important factor for her participation. Instead of 
forcing them, they should be convinced in the benefits of such seminars. Otherwise, they might not have a positive influence on the participants. Gamze said:

They force you to attend seminars that you do not believe in their importance. You are not even aware what the content is about. You do not have a choice to select the seminar, its date or the venue. Your seminar is the very first one that I have enjoyed and learned a lot. Best of all, it was voluntary-based, and I freely chose to attend.

Everyone was bored. The teachers in this project indicated that before applying the constructivist principles in their classes, they were teaching by using traditional ways. Thus, their classes were boring. After applying constructivist methods, the teachers noticed that the students were happier and enjoyed learning, and participated more actively. The teachers started using the new techniques and methods they learned during the seminar. When the teachers got positive feedback, they got more motivated and excited, and were willing to continue with those new teaching activities. Zeynep said,

You can see the excitement, the willingness and joy in the eyes and actions of the students when you apply those constructivist techniques. I, myself, have started enjoying teaching now, as well. In spite of encountering many difficulties and feeling tired, I really enjoyed and am pleased to do it. They are all worth it.

Ebru admitted, "Not only children, but also I was getting bored while having the classes in a traditional way, and the time was hardly passing. But now, we all enjoy and never realize how time passes."

Everyone was happy. As the participants expressed, with the non-traditional ways of teaching, the students got more excited and eager in the English lessons. Further, the teachers were happier than before, as well. Even, the families were glad to see their children enjoying learning English and getting involved in extracurricular activities related to English.

The teachers stated that their students were unenthusiastic in the classes at the very beginning due to their not being able to learn and understand English as a foreign language. However, when the teachers used constructivist methods and techniques, students got involved and started to enjoy the English classes. These findings of the current study supported some studies (Hisar, 2006; Yildiz, 2006) in the literature in which it was stated that the constructivist methodology was much better in terms of teaching English. Zeynep stated, "I have no more boring classes now. The class teaching occurs in an entertaining atmosphere. Moreover, my classes are interactive, not one speaks and others listen".

Helps every level of student. Another development was, for the very first time, these teachers experienced great improvement on getting the least participating, and most unwilling students involved. Those students improved greatly. This finding supports the literature (Lund, 2020), as well.

As Ebrar admitted, "To be honest, I wasn't expecting this performance from that child." With the traditional system, this student would have been blamed for educational failure or unfairly labeled as a problem and incapable of learning. However, the teachers whose perspectives and approach changed, and as a result who became critically reflective of their own teaching showed 
that with the constructivist approach all kinds of students could be given the chance to reveal their skills and abilities. Hale expressed,

My class is known as full of lazy and uninterested students particularly in English, at least among my colleagues. And no one wants to teach in that class. However, this is not the case when I teach in that class. I swear, even the laziest student raises his hand, participates in the discussions a lot. Some teachers are so surprised with this success. Even one of them asked "What are you doing to these students? How do you manage this?"

Constructivism is more effective in teaching. Another finding of this project was that constructivist approaches and its applications were more effective than traditional ways and methods in teaching English. The teachers in this project stated that some of their strategies helped students get interested and enthusiastic in the classes and got them involved.

This finding supports the studies (Agopian, 2019; Hisar, 2006; Yildiz, 2006) in the literature that showed constructivist methods of using various techniques and materials made the students get very interested and enthusiastic. Further, these students were more successful in learning English compared to the students who were taught in traditional ways. Hale said,

Look, these students were having English classes for years, and all-yearlong, and at the end, if you asked them what they remembered, nothing! Maybe, one or two students could remember some vocabulary, that's all. However, things have changed now. I would say, my students remember what they learned during the in-class activities. They make up sentences and are eager to speak. They can sing English songs and read English poems. They really learn. The artifacts, outcomes, pictures on the classroom walls draw the attention of the teachers from other disciplines, as well. Many times, I've heard them saying that they should apply such activities in their classes. Even the parents noticed the difference with the students.

Motivation. The literature indicates that students learn when they were motivated with the need and desire (von Glasersfeld, 1995). Motivation not only helped foreign language learning, but was also essential for learning in general (Agopian, 2019; Can, 2007; Cetinkaya, 2005; Demirel, 2003; von Glasersfeld, 1995). The findings of this study supported the literature. In some classes, the students were so motivated, they did not want to finish and leave the class. Zeynep said,

During the seminar, I learned the importance of motivation in learning. The students need motivation, otherwise they don't have a reason to learn English. That's one of the things I did. I observed that it's so strong. For instance, before, the students were running out of the class as soon as the bell rang. Now, they want to stay and continue the class activities even during the break time.

When students experienced the need to use the language, one way or another they used it. For instance, when teachers consistently spoke English without a single word of Turkish, the students started to understand and speak as well. 
Seminar effect continued. It was realized that the effects of the teacher development seminar continued even after the data collection process was over. For example, two of the participants, Ebrar and Zeynep, were offered to give seminars on constructivism to the teachers in a district in Ankara. They accepted the invitation willingly and confidently. They accomplished their job more successfully than they had anticipated. They were surprised at themselves and their own abilities for handling such a seminar.

On a phone call, they were so excited to tell the researcher about their experience of giving a seminar. They admitted that the teacher development seminar was quite helpful and constructive. Further, the collaborative and deliberative discussions that they had both during and after the seminar with the researcher and other colleagues were inspirational that in turn contributed to their successes a lot. Ebrar said,

I was applauded, praised and appreciated very much! I don't know, but somehow, I was able to answer every question posed to me about the applications of constructivism. I think, I internalized the knowledge I gained during the seminar.

Zeynep said,

You should have seen me on the stage. My presentation was like a standup show. The teachers were enjoying, and also learning. They did not let me go for a long time after the seminar. You should have seen what they wrote on the anonymous feedback papers. "Thank you for everything!"

Professional community and critical conversation groups. One prominent finding and outcome of this project was the establishment of a professional community and critical conversation groups during the teacher development seminar and data collection process in fall 2014 semester. Such professional interactions improved knowledge and skills, and classroom practices (Garet et al., 2001; Rohmah, 2018). The participants realized the importance of opportunities to work together, be reflective, and exchange ideas and strategies (Guskey, 2003). They also saw that collective wisdom helps more than individual ones in terms of teaching practices and student learning, and intellectual improvement (Birchak et al., 1998; Grossman, Wineburg, \& Woolworth, 2000).

\section{Policy Implications}

The study revealed that the teacher was the most important key person in implementing the new educational system and policy change. In that regard, the teachers should be trained, motivated, and convinced of the importance of applying the constructivism as a new notion in teaching English through well-planned and well-organized teacher development seminars. They should also be provided with ongoing support with the help of professional communities and study groups.

Teachers should be included in seminar planning and organization. The professional development seminars organized by the MoNE are not considered as satisfying by the participants. Therefore, as one of the participants indicated, it may be better to involve the teachers while planning such seminars. Their comments and ideas on the content and organization of the seminars should be taken into consideration in order to get more effective and efficient results. 
Another implication would be to follow up with the participants. The presenter of the seminars should be in continued contact, collaboration, and deliberation with the participants even after the seminar. The current study's findings showed that it was helpful and beneficial for the participants to keep in touch with the researcher after the professional development seminar.

The presenter could easily be reached whenever needed. However, in reality and in the context of Turkey, where there is a centralized education system with more than one million teachers registered to $\mathrm{MoNE}^{2}$, it is not easy to expect such an application nationwide. One of the alternative ways could be assigning teacher trainers or curriculum development experts in the related divisions of education departments in each city. So, the teachers could easily reach them to consult with any questions, problems, and challenges.

Some of the participants complained about the overcrowded classes, where they had difficulty in applying constructivist methods and activities. It is important to have a reasonable number of students in the classrooms for more effective and efficient results in students' learning.

The evaluation and assessment system should be revised; instead of outcome-based tests, process-based evaluation techniques, such as self-evaluation, peer evaluation, presentations and projects, and portfolios should be preferred.

\section{Limitations}

No study is exempt from weaknesses. Even though the researcher was careful and planned the study to reduce the limitations that might exist during the research, there were some limitations that she could not control. Some of them are as follows:

- This qualitative study is limited to six English teachers working in two public schools in Ankara. It was based on their subjective evaluations, understandings, and perceptions of the issue. Therefore, it does not represent the other cities or the whole Country.

- This study was limited to female teachers only. It did not reflect the male views and actions. It was not intended to select the participants as females; however, the participant selection process developed that way.

- This study sees the issue from six public school English teachers' points of view. It would have been even better if some other data had been collected from the students, administrators, and families to look at the issue from multi-angle perspectives.

\section{Conclusion}

Turkey made an education reform in 2005, accepted and applied a new approach, namely, the constructivism. In this context, the MoNE prepared a new curriculum based on constructivist principles. All teachers working in the public schools throughout the country used the same curriculum that was designed and controlled by the Ministry of National Education. The new curriculum looked perfect on the paper. However, not many changes in practice had been observed in terms of constructivist teaching and learning. First of all, the teachers as the key implementers of this new approach were not trained on constructivism as a new notion in education and prepared well for the change. Second, although a switch into constructivist education was done by The MoNE, the evaluation and assessment system as an important aspect of the whole education system was not changed accordingly and stayed the same. Third, the physical conditions and classrooms

\footnotetext{
${ }^{2}$ Official Website is https://sgb.meb.gov.tr/
} 
(overcrowded with 30+ students per room, few teacher resources) were not designed with constructivist principles in mind.

The teachers were successful in applying the new approach in practice despite the fact that they faced many challenges and obstacles in their applications in their schools. Once the participants internalized the principles of constructivism really well, these obstacles did not prevent them from applying the constructivist teaching methods and techniques. They were all dedicated teachers, and spent much more time, energy, and effort for their teaching activities in this new approach. At the end, they were tired, but thought it was worth it as they witnessed the students to be happier, to be more eager to learn, and to enjoy learning English.

In conclusion, the findings of this study revealed that the teacher development seminar had a positive effect on six selected English teachers working in two public schools in the city of Ankara in Turkey in changing their teaching views, approach, and applications. The impact was so substantial that the professional community that was formed during the seminar has been continuing since the end of this project, with the participation of new members.

For triangulation, different kinds of instruments and methods such as the participant periodic interviews, in-class observational fieldnotes and artifacts, and researcher logs were used (Lincoln \& Guba, 1984). Further, peer debriefing and member checking techniques were also used to increase the credibility of the study.

This study provided answers to some questions. However, there are also other questions yet to be explored. For example, how would professional development look in a case where the teachers in the whole country would be trained in constructivist approach in a constructivist way? Would the teacher development seminar be as effective when the group of participants in the group were more than six? All teachers in this study were female. Would gender make a difference in terms of teacher change and insight? Would the results differ if some other stakeholders, such as administrators and students in the schools were involved in the research? Perhaps future researchers will have the opportunity to explore these questions.

\section{References}

Agopian, T. (2019). Inductive grammar, student-centered reading, and interactive poetry: The effects of teaching English with fun in schools of two villages in Lebanon. International Journal of Educational and Pedagogical Sciences, 11 (3), 303-311.

Aksoy, E., Bozdogan, D., Akbas, U., \& Seferoglu, G. (2018). Old wine in a new bottle: Implementation of intensive language program in the 5th grade in Turkey. Eurasian Journal of Applied Linguistics, 4 (2), 301-324. doi: 10.32601/ejal.464187

Ashraf, T. A. (2021). Problems of teaching overcrowded EFL classes in Saudi Arabia. Language in India, 21(1), 81-97.

Aykac, N. (2007a). The teachers' opinions about the elementary social science lesson programme. Elektronik Sosyal Bilimler Dergisi, 6(22) 46-73. www.esosder.org

Aykac, N. (2007b). Evaluation of activities in primary education programme with the teachers' views (sample of Sinop province). Ahi Evran Üniversitesi Kırşehir Eğitim Fakültesi Dergisi (KEFAD), 8(2), 19-35.

Aykac, N., \& Ulubey, O. (2012). Pre-service teachers' opinions about the application level of elementary school program. Journal of Faculty of Educational Sciences, 45(1), 63-82.

Ayu, M. (2019). Interactive activities for effective learning in overcrowded classrooms. Linguists: Journal of Linguistics and Language Teaching, 4(2), 1-6. doi:http://dx.doi.org/10.29300/ling.v4i2.1658 
Ayvaz-Tuncel, Z., \& Cobanoglu, F. (2018). In-service teacher training: Problems of the teachers as learners. International Journal of Instruction, 11(4), 159-174. https://doi.org/10.12973/iji.2018.11411a

Babinski, L. M., Amendum, S. J., Knotek, S. E., Sánchez, M., \& Malone, P. (2018). Improving young English learners' language and literacy skills through teacher professional development: A randomized controlled trial. American Educational Research Journal, 55(1), 117-143. https://doi.org/10.3102/0002831217732335

Baglibel, M., Samancioglu, M., \& Crow, G. M. (2018). Factors affecting the sustainability of educational changes: A mixed method research. Cogent Education, 5(1), 1-14. https://doi.org/10.1080/2331186X.2018.1502395

Bamgbose, A. (2003). A recurring decimal: English in language policy and planning. World Englishes, 22(4), 419-431.

Bednarz, \& J. Garrison (Eds.), Constructivism and education (pp. 23-28).

Birchak, B., Connor, C., Crawford, K. M., Kahn, L. H., Kaser, S., Turner, S., \& Short, K. G. (1998). Teacher study groups: building community through dialogue and reflection. National Council of Teachers of English (NCTE). http://files.eric.ed.gov/fulltext/ED424584.pdf

Brooks, J. G., \& Brooks, M. J. (1999). In search of understanding: The case for constructivist classrooms. Alexandria, VA: Association for Supervision and Curriculum Development.

Brown, H. D. (2000). Principles of language learning and teaching (4th ed.). White Plains, NY: Longman.

Buyukduman, F. I. (2005). The opinions of elementary school English teachers on the English curriculum for elementary schools. Hacettepe Üniversitesi Egitim Fakültesi Dergisi, 28, 55-64.

Cakiroglu, E., \& Cakiroglu, J. (2003). Reflections on teacher education in Turkey. European Journal of Teacher Education, 26(2), 253-264.

Cambourne, B. (2001). Conditions for literacy learning: Why do some students fail to learn to read? Ockham's Razor and the Conditions of Learning. The Reading

Cambridge, UK: Cambridge University Press.

Can, T. (2007). Constructivist education. WordPress. https://constructivism.wordpress.com/

Can, T. (2009). Language development, language learning theories, Piaget, Vygotsky, Bruner and Constructivism. Ingilish. http://www.ingilish.com/Constructivism.htm

Cetinkaya, Y. B. (2005). Turkish college students' willingness to communicate in English as a foreign Language [Unpublished doctoral dissertation]. Ohio State University.

Creswell, J. C. (2007). Qualitative inquiry \& research design: Choosing among the five approaches (2nd ed.). Thousand Oaks, CA: Sage.

Creswell, J. C. (2009). Research design: Qualitative, quantitative, and mixed methods approaches. (3rd ed.). Thousand Oaks, CA: Sage.

Demir-Ayaz, A., Ozkardas, S., \& Ozturan, T. (2019). Challenges of English language teaching in high schools in Turkey and possible suggestions to overcome them. Eurasian Journal of Applied Linguistics, 5(1), 41-55. https://doi.org/10.32601/ejal.543778

Demircan, O. (1988). Foreign language teaching in Turkey: Past to present. Istanbul, Turkey: Remzi.

Demirel, O. (2003). Foreign language teaching. Ankara, Turkey: Pegem Publications.

Dewey, J. (1916). Democracy and education. New York, NY: The McMillan Company.

Dogancay-Aktuna, S., \& Kız1ltepe, Z. (2005). English in Turkey. World Englishes, 24(2), 253-265. 
Donmez, O. (2010). Implementation of the new eighth grade English language curriculum from the perspectives of teachers and students [Unpublished master's thesis]. Middle East Technical University.

Er, K. O. (2006). Evaluation of English curricula in 4th and 5th grade primary schools. Journal of Faculty of Educational Sciences, 39(2), 1-25.

Ersen-Yanik, A. (2008). Primary school English teachers' perceptions of the English language curriculum of 6th, 7th and 8th grades. Hacettepe Üniversitesi Egitim Fakültesi Dergisi, 35, 123-134.

Fullan, M. (1993). Why teachers must become change agents. Educational Leadership, 50(6), 1217.

Fullan, M. (2001). The new meaning of educational change. New York, NY: Teachers College Press.

Fullan, M. (2007). Change the terms for teacher learning. National Staff Development Council, 28(3), 35-36.

Gao, R. (2021). The vocabulary teaching mode based on the theory of constructivism. Theory and Practice in Language Studies, 11(4), 442-446. https://doi.org/10.17507/tpls.1104.14

Garet, M. S., Porter, A. C., Desimone, L., Birman, F. B., \& Yoon, K. S. (2001). What makes professional development effective? Results from a national sample of teachers Author(s). American Educational Research Journal, 38(4), 915-945.

Garmston, R. (1987). How administrators support peer coaching. Educational Leadership, 44(5), 18-26.

Geringer, J. (2003). Reflections on professional development: Toward high-quality teaching and learning. Phi Delta Kappan, 84(5), 373-375.

Gokmenoglu, T., Clark, C., \& Kiraz, E. (2016). Professional development needs of Turkish teachers in an era of national reforms. Australian Journal of Teacher Education, 41(1). 113125.

Goodman, K. 2005. What's whole in whole language. Berkeley, CA: RDR Books.

Grossman, P., Wineburg, S., \& Woolworth, S. (2000). What makes teacher community different from a gathering of teachers? An occasional paper. Seattle, WA: Center for the Study of Teaching and Policy.

Guskey, T. R. (2002). Professional development and teacher change. Teachers and Teaching: Theory and Practice, 8(3/4), 381-391.

Guskey, T. R. (2003) What makes professional development effective? Phi Delta Kappan, 84(10), 748-750.

Hargreaves, A., \& M. G. Fullan. (1992). Introduction. In A. Hargreaves \& M. G. Fullan (Eds.), Understanding teacher development (pp. 1-19). New York, NY: Teachers College Press, Columbia University.

Hisar, S. G. (2006). An experimental study of useable effective learning methods on 4th and 5th grade English lessons [Unpublished master's thesis]. Suleyman Demirel University.

Holly, M. L., Arhar, J. M., \& Kasten, W. C. (2009). Action research for teachers: Traveling the yellow brick road (3rd ed.). Boston, MA: Allyn \& Bacon.

Johnson, D. W., \& Johnson, R. T. (1987). Research shows the benefits of adult cooperation. Educational Leadership, 44(2), 27-30.

Joyce, B., \& Showers, B. (1982). The coaching of teaching. Educational Leadership, 40(1), 4-10.

Joyce, B., \& Showers, B. (1987). Low-cost arrangements for peer coaching. Journal of Staff Development, 8(1), 22-24. 
Kara, E., Ayaz, A., \& Dundar, T. (2017). Challenges in EFL Speaking Classes in Turkish Context. European Journal of Language and Literature, 3(2), 66-74.

Kavanoz, S. H. (2006). An exploratory study of English language teachers' beliefs, assumptions, and knowledge about learner-centeredness. The Turkish Online Journal of Educational Technology, 5(2), 3-9.

Kirkgoz, Y. (2005). English language teaching in Turkey: Challenges for the $21^{\text {st }}$ century. In G. Braine (Ed.), Teaching English to the world: History, curriculum, and practice (pp. 159175). Mahwah, NJ: Lawrence and Erlbaum Associates.

Kirkgoz, Y. (2009). Globalization and English language policy in Turkey. Educational Policy, 23(5), 663-684.

Knowles, M. S. (1996). Adult learning. In R. L. Craig (Ed.), The ASTD training \& development handbook: A guide to human resource development (pp. 253-266). New York, NY: McGraw-Hill.

Kucukler, H., \& Kodal, A. (2019). Foreign language teaching in over-crowded classes. English Language Teaching, 12 (1), 169-174. doi: 10.5539/elt.v12n1p169

Lincoln, Y. S., \& Guba, E. G. (1984). Naturalistic inquiry. Beverly Hills, CA: Sage.

Lou, W. (2008). Cultivating the capacity for reflective practice: A professional development case study of L2/EFL teachers [Unpublished doctoral dissertation]. Kent State University

Luk, N. (2006). Cornerstones of Turkish education from the Ottoman to the post-republic Turkey: A history of English language teaching in Turkey [Unpublished doctoral dissertation]. University of Pennsylvania.

Lund, L. (2020). When school-based, in-service teacher training sharpens pedagogical awareness. Improving Schools, 23 (1), 5-20.

MacKinnon, A., \& Scarff-Seatter, C. (1997). Constructivism: Contradictions and confusion in teacher education. In V. Richardson (Ed.), Constructivist teacher education: Building new understandings (pp.38-55). Washington, DC: Falmer Press.

Mitchell, R., \& Myles, F. (2004). Second language learning theory (2 ${ }^{\text {nd }}$ ed.). New York, NY: Oxford University Press.

MoNE. (2009). http://www.meb.gov.tr/

Moore, J. R. (1988). Guidelines concerning adult learning. Journal of Staff Development, 9(3), 2 5.

Munoz, D. P. (2007). Exploring five Mexican English language teachers' perceptions of their professional development and its relation to autonomy. English Language Teacher Education and Development (ELTED), 10, 19-30.

Nolan, J. F., \& Meister, D. G. (2000). Teachers and educational change: The lived experience of a secondary school restructuring. New York, NY: SUNY Press

Noom-ura, S. (2013). English-teaching problems in Thailand and Thai teachers' professional development needs. English Language Teaching, 6(11), 139-147.

Oxford, R. L. (1997). Constructivism: Shape-shifting, substance, and teacher education applications. Peabody Journal of Education, 72(1), 35-66.

Piaget, J. (1973). To understand is to invent. New York, NY: The Viking Press.

Pugach, M. C., \& Johnson, L. J. (1990). Developing reflective practice through structured dialogue. In R. Clift, W. Houston, \& M. Pugach (Eds.), Encouraging reflective practice in education (pp. 187-207). New York, NY: Teachers College Press.

Reinfried, M. (2000). Can radical constructivism achieve a viable basis for foreign language teaching?: A Refutation of the 'Wolff-Wendt' Theorem. Erfurt Electronic Studies in English $(E E S E)$. http://webdoc.sub.gwdg.de/edoc/ia/eese/journal_frame.html 
Richards, J. C., \& Farrell, T. S. C. (2005). Professional development for language teachers: Strategies for teacher learning. New York, NY: Cambridge University Press.

Richards, J. C., \& Nunan, D. (1990). Second-language teacher education. New York, NY: Cambridge University Press.

Richardson, V. (1990). Significant and worthwhile change in teaching practice. Educational Researcher, 19(7), 10-18.

Robbins, P. (1991). How to plan and implement a peer coaching program. Alexandria, VA: Association for Supervision and Curriculum Development.

Rohmah, Z. (2018). Enhancing English teachers' professional development: portraying a $\begin{array}{llll}\text { mentoring } & \text { program. TEFLIN }\end{array}$ https://doi.org/10.15639/teflinjournal.v29i1/90-107

Rubin, H. J., \& Rubin, I. S. (2005). Qualitative interviewing: The art of hearing data. Thousand Oaks, CA: Sage.

Sad, S. N. (2010). Theory-practice dichotomy: Prospective teachers' evaluations about teaching English to young learners. Journal of Language and Linguistic Studies, 6(2), 22-53.

Seferoglu, S. S. (1996). Exploring elementary school teachers' perceptions of professional development: The Turkish case. A paper presented at the Annual Meeting of the American Educational Research Association, New York. ERIC Document

Sessions, M. J. (1995). An analysis of a method for training educators in the peer coaching process [Unpublished doctoral dissertation]. Iowa State University.

Showers, B. (1982). Transfer of training: The contribution of coaching. Eugene, OR: Center for Educational Policy and Management

Showers, B. (1984). Peer coaching: A strategy for facilitating transfer of training. Eugene, OR: Center for Educational Policy and Management.

Showers, B. (1985). Teachers coaching teachers. Educational Leadership, 42(70), 43-49.

Stein, M. K., \& Wang, M. C. (1988). Teacher development and school improvement: The process of teacher change. Teaching and Teacher Education, 4(2), 171-187.

Tante, C. A. (2010). The purpose of English Language teacher assessment in the English-speaking primary school in Cameroon. English Language Teacher Education and Development (ELTED), 13, 27-39.

Teacher, 54(8), 784-786.

Tomlinson, A. C. (2019). Collegial conversations can fuel teacher growth. ASCD. https://www.ascd.org/el/articles/collegial-conversations-can-fuel-teacher-growth

Topkaya, E. Z., \& Kucuk, O. (2010). An evaluation of 4th and 5th grade English language teaching program. Ilkögretim Online, 9(1), 52-65.

Ulum, O. G., \& Uzun, K. (2020). Critical perspective of English teaching and learning in Turkey. International Journal of Evaluation and Research in Education (IJERE), 9(2), 456-460.

von Glasersfeld, E. (1995). Radical constructivism: A way of knowing and learning. Bristol, PA: The Falmer Press.

von Glasersfeld, E. (1998). Why constructivism must be radical. In M. Larochelle, N.

Vygotsky, L. (1978). Mind in society: The development of higher psychological processes. Cambridge, MA: Harvard University Press.

Yesilcinar, S., \& Cakir, A. (2018). Continuing professional development process: English language teachers ${ }^{\text {ee }}$ views on the role of teacher research. Journal of Language \& Linguistics Studies, $14(2), 61-75$.

Yildiz, E. (2006). The implementation of constructivism in English language teaching for Turkish learners [Unpublished master's thesis]. Selçuk Üniversitesi, Sosyal Bilimler Enstitüsü. 
Yilmaz, K. (2009). Democracy through learner-centered education: a Turkish perspective. International Review of Education, 55(1), 21-37.

\section{Notes on Contributors}

Arzu Gul, Ph.D., is the ESL Bridge Program Coordinator at State University of New York (SUNY) in Plattsburgh. She has a master's degree in Teaching English as a Second Language (TESL) and a doctoral degree in Curriculum and Instruction, both from Kent State University. She has had experience in teaching ESL courses both in Turkey and United States for over 30 years. In addition, she has been tutoring and co-teaching conversation sessions for adult language learners for Literacy Volunteers of Clinton, Essex, and Franklin Counties of New York. She also served on several committees in the Ministry of National Education in Turkey.

Wendy C. Kasten, Ph.D., is Professor Emerita from Kent State University where she was part of the School of Teaching, Learning, \& Curriculum Studies in Reading, Writing and Language Arts. Kasten worked with international students from 16 different countries, and worked on many international projects. She is co-author of Living Literature: Using Children's Literature to Support Reading and Language Arts, other books, including two published in Turkey, articles, chapters, and monographs. 


\section{Appendix}

\section{Data Kodlama Örneği (Turkish Original)}

\begin{tabular}{|c|c|c|c|c|c|c|c|c|}
\hline Soru & Tema & $\begin{array}{l}\text { Tema } \\
\text { Frekans }\end{array}$ & K1 & $\mathrm{K} 2$ & K3 & K4 & K5 & K6 \\
\hline \multirow[t]{2}{*}{$\begin{array}{l}\text { Öğretmen } \\
\text { gelişim } \\
\text { seminerinde } \\
\text { n sonra, } \\
\text { Türkiye'de } \\
\text { yabancı dil } \\
\text { eğitimi ile } \\
\text { ilgili ne tür } \\
\text { vizon } \\
\text { kazanımları } \\
\text { nız oldu? }\end{array}$} & $\begin{array}{l}\text { Komple } \\
\text { değişim }\end{array}$ & 2 & & & & $\begin{array}{l}\text { “Görüşüm, } \\
\text { bakışım ve } \\
\text { neredeyse } \\
\text { ögretme ile } \\
\text { ilgili her } \\
\text { şeyim } \\
\text { değissti. Hem } \\
\text { teorik hem } \\
\text { örnekler } \\
\text { hem de } \\
\text { gösterdiğiniz } \\
\text { uygulamalar } \\
\text { ı bir araya } \\
\text { getirdiğimiz } \\
\text { de bana çok } \\
\text { faydası } \\
\text { olduğunu } \\
\text { düşünüyoru } \\
\text { m.” }\end{array}$ & & \\
\hline & $\begin{array}{l}\text { Yapılandır } \\
\text { macılıkla } \\
\text { örtüşme } \\
\\
\text { Ogrenci } \\
\text { merkezli } \\
\text { Yasam } \\
\text { icinde }\end{array}$ & 1 & $\begin{array}{l}\text { "Yabanci dil } \\
\text { ogretiminin } \\
\text { yapilandirm } \\
\text { aci } \\
\text { yaklasimla } \\
\text { birebir } \\
\text { ortustugunu } \\
\text { bu yontemin } \\
\text { yabanci dil } \\
\text { ogretiminde } \\
\text { kullanilmasi } \\
\text { gerektigini } \\
\text { bir kez daha } \\
\text { animsadim.Y } \\
\text { abanci dilin } \\
\text { de ana dil } \\
\text { gibi zaman } \\
\text { icinde } \\
\text { edinilmesi } \\
\text { gerektigini } \\
\text { ve bunu } \\
\text { saglamak } \\
\text { icin de } \\
\text { ogrencilerin } \\
\text { merkeze } \\
\text { alinip } \\
\text { yaparak } \\
\text { yasayarak } \\
\text { bizzat } \\
\text { uygulayarak } \\
\text { hayattan } \\
\text { kopmadan }\end{array}$ & & & & & \\
\hline
\end{tabular}




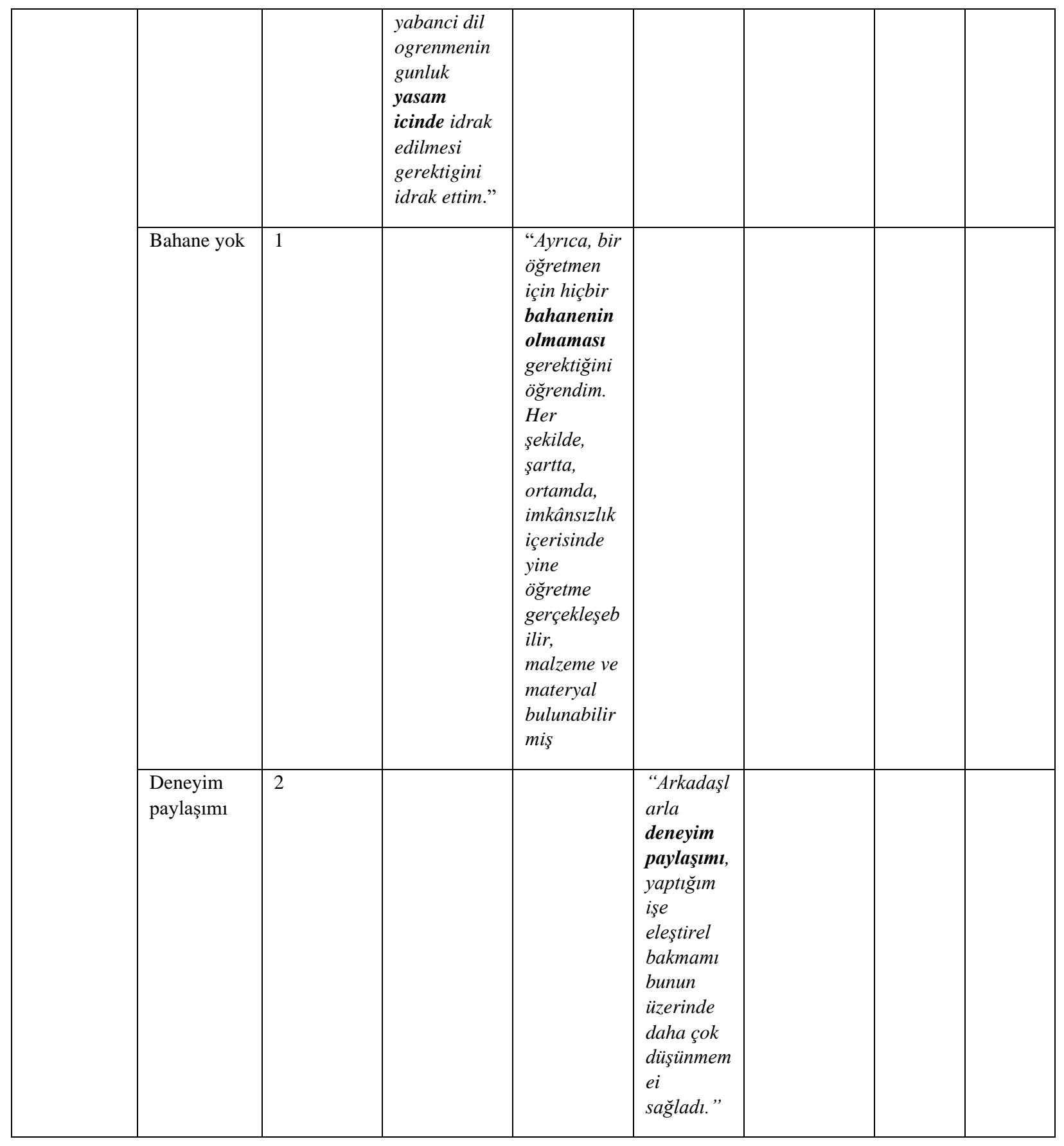


A Sample of Data Coding (English Translation)

\begin{tabular}{|c|c|c|c|c|c|c|c|c|}
\hline Question & Theme & Frequency & P1 & P2 & P3 & P4 & P5 & P6 \\
\hline \multirow[t]{2}{*}{$\begin{array}{l}\text { What } \\
\text { insights do } \\
\text { you think } \\
\text { you gained } \\
\text { by } \\
\text { participating } \\
\text { in a } \\
\text { professional } \\
\text { development } \\
\text { program in } \\
\text { foreign } \\
\text { language } \\
\text { teaching in } \\
\text { Turkey? }\end{array}$} & $\begin{array}{l}\text { Total } \\
\text { Change }\end{array}$ & 2 & & & & $\begin{array}{l}\text { "My view, } \\
\text { the way I } \\
\text { look at } \\
\text { teaching.I } \\
\text { would say, } \\
\text { everything } \\
\text { about my } \\
\text { teaching has } \\
\text { changed } \\
\text { totally. All } \\
\text { those } \\
\text { theories, } \\
\text { examples, } \\
\text { and the } \\
\text { Constructivi } \\
\text { st techniques } \\
\text { you shared } \\
\text { with us were } \\
\text { helpful and } \\
\text { contributed } \\
\text { to that } \\
\text { change." }\end{array}$ & & \\
\hline & $\begin{array}{l}\text { Constructiv } \\
\text { ism fits }\end{array}$ & (1) & $\begin{array}{l}\text { "I realized } \\
\text { that } \\
\text { Constructivi } \\
\text { sm fits the } \\
\text { best, } \\
\text { therefore, } \\
\text { should be } \\
\text { used in } \\
\text { foreign } \\
\text { language } \\
\text { teaching in a } \\
\text { daily life. In } \\
\text { order to do } \\
\text { that, foreign } \\
\text { language } \\
\text { should be } \\
\text { taught in } \\
\text { student- } \\
\text { centered } \\
\text { format. They } \\
\text { should learn } \\
\text { by doing and } \\
\text { experiencing } \\
\text {, and seeing } \\
\text { real-life } \\
\text { connection } \\
\text { in the } \\
\text { subject } \\
\text { matter". }\end{array}$ & & & & & \\
\hline
\end{tabular}




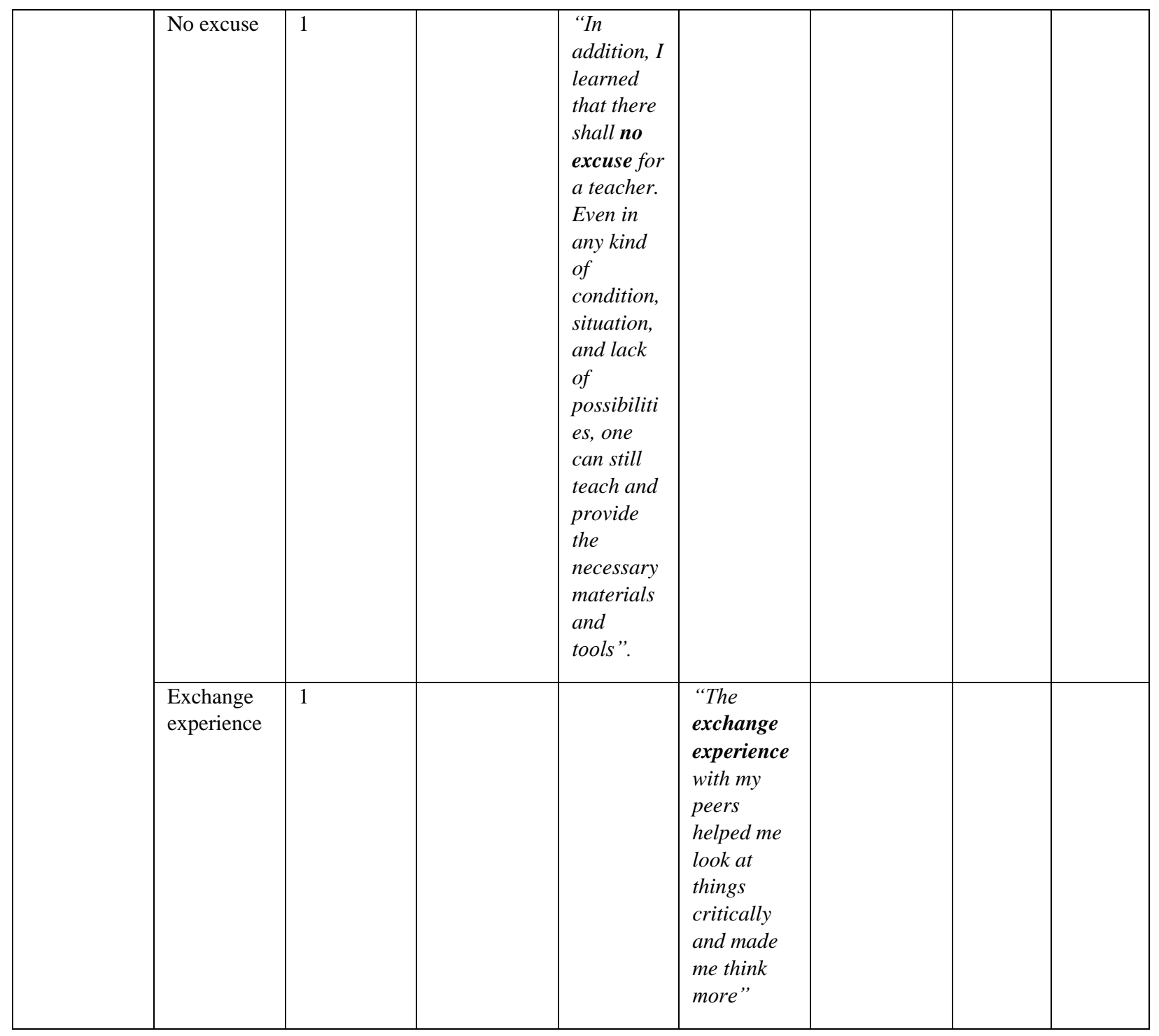

